\title{
Evaluation of Medication and Herbal Product Use Among Pregnant Women
}

\author{
Rashida Muhammad UMAR ${ }^{1}$, Rabia BEŞİROĞLU ${ }^{1}$, Ayşe Kevser ŞAHINN¹, Emine Karataş \\ KOÇBERBER ${ }^{2}$, Cengizhan CEYLAN ${ }^{3^{*}}$ \\ 1 İstanbul Medipol University, School of Pharmacy, Department of Clinical Pharmacy \\ 2 Marmara University, Institute of Health Sciences, Department of Clinical Pharmacy \\ 3 Selçuk University, Faculty of Pharmacy, Department of Clinical Pharmacy
}

\begin{abstract}
The use of medications and herbal products among women increases after pregnancy. The purpose of the study is to evaluate the frequency of medication used and analyzed them based on the FDA pregnancy risk categories. This cross-sectional study was conducted on 300 adult volunteers attending antenatal care in a university-affiliated hospital. Medications were classified according to the FDA pregnancy risk classification. In $97,7 \%$ of women, the use of at least one medication during pregnancy. The median count for Category A medications was 2. Category C and $\mathrm{B}$ medications were reported by $100(33,3 \%)$ and 53 women (17,7\%). There was a significant difference between the education level and the use of herbal products $(\mathrm{p}=0.043)$. Pharmacists should take a greater role in educating pregnant women and women of childbearing age about the possible consequences of medications on the development of the fetus and guide healthcare practitioners in choosing the most appropriate medications.
\end{abstract}

Key words: Medication use, herbal product use, pregnancy, FDA risk category

\section{INTRODUCTION}

The use of medications and herbal products is common among pregnant women. Medications may be needed for treatment in various conditions related to the mother and fetus during pregnancy. It has been reported that many pregnant women are prescribed drugs and they tend to use these prescription

\footnotetext{
${ }^{*}$ Corresponding author: e-mail: c.ceylan20@gmail.com ORCIDs:

Rashida Muhammad UMAR : https://orcid.org/0000-0001-8902-7274

Rabia BEŞiROĞLU : : https://orcid.org/0000-0003-3188-4278

Ayşe Kevser ŞAHIN : : https://orcid.org/0000-0003-0223-2959

Emine Karataş KOÇBERBER : https://orcid.org/0000-0003-2803-0992

Cengizhan CEYLAN : : https://orcid.org/0000-0003-4164-9212

(Received 21 February 2021, Accepted 3 June 2021)
} 
$\operatorname{drugs}^{1,2}$. There is no doubt that the unjustifiable use of medications is common even during pregnancy ${ }^{3}$. In a multi-center study involving 9459 women, it was found that $81 \%$ of pregnant women used at least one medication (with or without prescription) during their pregnancy ${ }^{4}$. In another cross-sectional study, it was found that $56 \%$ of pregnant women used herbal supplement during their pregnancy 5 .

The use of some medications and malnutrition during pregnancy have been associated with increase in the risk of some health conditions like schizophrenia, fertility disorder, metabolic problems, diabetes mellitus and cardiovascular diseases in developing fetus ${ }^{6}$. Teratogenic and embryo-fetotoxic effects of medications are related to the dose, route of administration, time of exposure, rate of exposure and genetic predisposition to the effect of a particular medication 7 and gestational age of the pregnancy. Before implantation, any abnormalities generally prevent implantation of the zygote. The most vulnerable period is the organogenesis stage where there is higher rate of cell division and development of organs ${ }^{8}$. A study revealed that the risk of congenital abnormalities is $2-3 \%$ and $2-5 \%$ of these abnormalities results from medication and chemical toxin exposure ${ }^{7}$. According to the 2014 European report, neurologic problems were present in $40 \%$ and other congenital malformations in $10 \%$ of newborns exposed to valproate ${ }^{1}$. As not all medications are studied in pregnant women, it is difficult to estimate the permeability of the medications into the placenta, its metabolism and elimination. It may also be unclear whether the teratogenic effect is caused by the main medication or its metabolites ${ }^{6}$.

Anatomical and physiological changes such as decreased gastrointestinal motility, increased gastric $\mathrm{pH}$, increased glomerular filtration rate, changes in the activities of liver enzymes that metabolize medications and changes in cardiac output are observed in pregnant women ${ }^{9,10}$. In the systematic review, it was stated that anticoagulants, antiretrovirals, antidepressants, antiepileptics, analgesics and anesthetics used during pregnancy should be re-dosed due to pharmacokinetic changes in their use during pregnancy ${ }^{11}$. The fetus is affected by these changes and this situation may cause anomalies ${ }^{12}$.

There is not enough data about the use of herbal products during pregnancy. Therefore, the US Food and Medication Administration (FDA) does not recommend the use of herbal products during pregnancy ${ }^{13}$. According to the studies conducted on medications used in pregnancy in our country, it has been concluded that the most common medication groups are antidepressants and antibiotics. It is stated that pregnant women mostly use medications in the first trimester according to the gestation period. It is known that the use of over- 
the-counter medications, which can be sold without a prescription, is $8.2 \%$ in our country, and unnecessary use is thought to be common ${ }^{14}$. The number of researches on the use of medications and herbal products in pregnant women is few in our country. It is necessary to determine the frequently used medications and risk categories during pregnancy. Guides should be prepared in the light of the available data ${ }^{15}$.

The aim of this study is to identify the prevalence of medication use among pregnant women and categorize the medications based on the FDA pregnancy risk classification.

\section{METHODOLOGY}

The cross-sectional study was carried out in a university-affiliated teaching hospital. Adult volunteers attending antenatal care where included in the study. The study was carried out between November 2016 - February 2017. The socio-demographic characteristics of patients were recorded using a standard patient information form. Information on medication use and herbal supplements during pregnancy were also recorded. Patients were asked to specify the need for the medication/herbal supplement use and whether they informed their doctors. Patients were also asked to state their preferred source of medication information when they have the need to use a medication or supplement.

\section{Classification of medications and herbal products}

The medications and supplements recorded were classified in accordance with the FDA classification of medications in pregnancy. Active ingredients in combined medications and supplements were evaluated individually. The FDA classification was checked online from Medscape medication information website (accessed date Nov 2016 - Feb 2017). Daily caffeine limit was taken to be 300 mg as recommended by the World Health Organization (WHO) ${ }^{16}$. The amount of caffeine in 1 cup of Turkish coffee has been evaluated as $82 \mathrm{mg}^{17}$. Only the number of herbal products used has been evaluated.

\section{Statistical analysis}

Descriptive statistics were given as mean \pm standard deviation and median [interquartile range (IQR) of $25 \%$ to $75 \%$ ] with minimum-maximum for continuous variables depending on their distribution. Numbers and percentages were used for categorical variables. Normality of the numerical variables was analyzed by the Kolmogorov-Smirnov test and checked by Q-Q plots and histograms. In comparing two independent groups, the Independent Samples t-test was used where numerical variables had a normal distribution. For variables 
without normal distribution, the Mann Whitney U test was applied. For comparison of differences between categorical variables, Fisher Freeman Halton test was used in RxC tables. Spearman Rho correlation coefficient was used to analyze the associations between numerical variables.

For statistical analysis and figures, Microsoft Office Excel and "Jamovi project (2020), Jamovi (Version 1.2.24) [Computer Software] (Retrieved from https:// www.jamovi.org) ve JASP (Version 0.13.1) (Retrieved from https://jasp-stats.org) were used. The significance level (p-value) was set at 0.05 in all statistical analyses.

\section{RESULTS AND DISCUSSION}

There were 300 participants with a mean age of 29,2 $\pm 4,3$ years. The majority of women were with university education (59\%). Most of the women (62,7\%) were in the third trimester. Details of obstetric history is given in Table 1. The education status of patients was high as $62,7 \%$ of patients were university graduates.

Table 1. Demographic characteristics and obstetric history of the participants $(n=300)$.

\begin{tabular}{|c|c|}
\hline Variables & \\
\hline Age $(\text { year })^{\dagger}$ & $29.2 \pm 4.3$ \\
\hline \multicolumn{2}{|l|}{ Educational status ${ }^{\ddagger}$} \\
\hline Primary & $34(11.3)$ \\
\hline Secondary & $78(26.0)$ \\
\hline University & $177(59.0)$ \\
\hline Higher & $11(3.7)$ \\
\hline \multicolumn{2}{|c|}{ Interview time for gestational period $\ddagger$} \\
\hline During 1st trimester & $40(13.3)$ \\
\hline During 2nd trimester & $72(24.0)$ \\
\hline During 3rd trimester & $188(62.7)$ \\
\hline Gravidity ${ }^{\beta}$ & $1.0[1.0-7.0]$ \\
\hline Parity ${ }^{\beta}$ & $0.0[0.0-5.0]$ \\
\hline Abortion ${ }^{\beta}$ & $0.0[0.0-3.0]$ \\
\hline
\end{tabular}

${ }^{+}:$Mean \pm standard deviation, ${ }^{*}: n(\%),{ }^{\beta}:$ median [range].

\section{Medication and herbal product use}

Data on overall medication use and medications stratified according to their categories are summarized in Table 2. In 97,7\% of women, there was a history of at least one medication during pregnancy. The median count of medications was 2. Although 285 women (95\%) reported prescription medication use, over-the-counter medication use was detected in 45 participants (15\%). In this study, 219 women (73\%) reported using herbal products during pregnancy. 
Table 2. Details of medication use in the study group $(n=300)$.

\begin{tabular}{|c|c|}
\hline Variables & \\
\hline Overall medication use ${ }^{\ddagger}$ & $293(97.7)$ \\
\hline Medication count ${ }^{\beta}$ & $2.0[0.0-7.0]$ \\
\hline Prescription medication use ${ }^{\ddagger}$ & $285(95.0)$ \\
\hline Medication count ${ }^{\beta}$ & $2.0[0.0-7.0]$ \\
\hline Over-the-counter medication use ${ }^{\ddagger}$ & $45(15.0)$ \\
\hline Medication count ${ }^{\beta}$ & $0.0[0.0-2.0]$ \\
\hline Herbal product use ${ }^{\ddagger}$ & $219(73.0)$ \\
\hline Medication count ${ }^{\beta}$ & $1.0[0.0-6.0]$ \\
\hline Use of Category A medication $\ddagger$ & $286(95.3)$ \\
\hline Use of Category B medication ${ }^{\ddagger}$ & $53(17.7)$ \\
\hline Use of Category $\mathrm{C}$ medication $\ddagger$ & $100(33.3)$ \\
\hline Use of Category D medication $\ddagger$ & $7(2.3)$ \\
\hline Use of Category $\mathrm{X}$ medication $\ddagger$ & $0.0(0.0)$ \\
\hline Medication count in category $A^{\beta}$ & $2.0[0.0-5.0]$ \\
\hline Medication count in category $\mathrm{B}^{\beta}$ & $0.0[0.0-2.0]$ \\
\hline Medication count in category $\mathrm{C}^{\beta}$ & $0.0[0.0-3.0]$ \\
\hline Medication count in category $D^{\beta}$ & $0.0[0.0-1.0]$ \\
\hline Medication count in category $X^{\beta}$ & $0.0[0.0-0.0]$ \\
\hline Medication use without knowing being pregnant ${ }^{\ddagger}$ & $43(14.3)$ \\
\hline Medication use without doctor recommendation ${ }^{\ddagger}$ & $17(5.7)$ \\
\hline \multicolumn{2}{|l|}{$\begin{array}{c}\text { Personal recommendation of a medication without } \\
\text { doctors' recommendation } \ddagger\end{array}$} \\
\hline Byself & $13(76.5)$ \\
\hline Friends & $1(5.9)$ \\
\hline Family members & $1(5.9)$ \\
\hline Unknown & $2(11.8)$ \\
\hline Medication use without information about its category ${ }^{\ddagger}$ & $43(14.3)$ \\
\hline Current herbal tea and medication count $\beta$ & $1.0[0.0-6.0]$ \\
\hline
\end{tabular}

${ }^{+}:$Mean \pm standard deviation, ${ }^{*}: n(\%),{ }^{\beta}:$ median [range].

Category A medications were the most frequently used throughout the pregnancy in 286 patients (95,3\%). The median count for Category A medications was 2. Category C and B medications were reported by 100 (33,3\%) and 53 women (17,7\%). Acetylsalicylic acid is in category D when used in the third trimester of pregnancy. Has been observed that the most frequently used drug in category D was acetylsalicylic acid.

In out of 17 women with over-the-counter medication use, 13 women $(76,5 \%)$ used these medications by themselves. 
The most commonly prescribed medications during pregnancy are antianemic medications (25,5\%), multivitamin and mineral combinations (19\%), vitamins (17\%), antacids (11,4\%), minerals and electrolytes (8\%), nutraceuticals $(4,8 \%)$, thyroid medications (3,5\%), progestin $(3,4 \%)$ and other $(7,4 \%)$ respectively. Details are given in Figure 1.

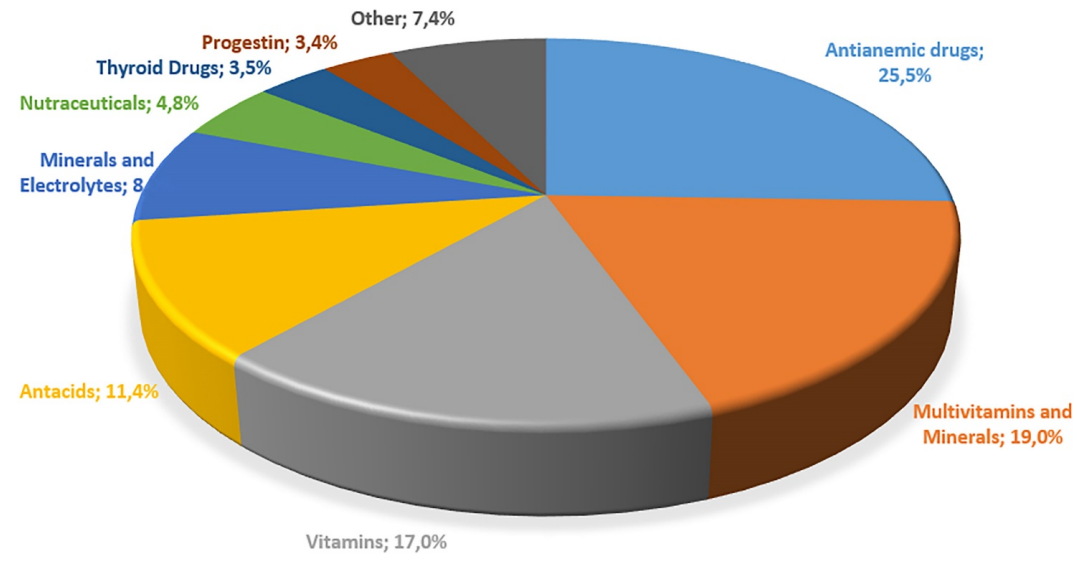

Figure 1: Prescription medications classification

There were no differences in age, educational status, interview time and gestational history between the participants with and without overall, prescription and over-the-counter medication uses, and use of medication without doctors' recommendation, ( $\mathrm{p}>0.05$ for all) details are given Table 3 .

Table 3. Comparison of demographic characteristics and obstetric history of the participants with different types of medication use.

\begin{tabular}{|c|c|c|c|c|c|c|}
\hline & \multicolumn{2}{|c|}{ Overall medication use } & & \multicolumn{2}{c|}{$\begin{array}{c}\text { Use of medication without doctors' } \\
\text { recommendations }\end{array}$} & \\
\hline & No (n=7) & Yes (n=293) & $\mathbf{p}$ & No (n=283) & Yes (n=17) & $\mathbf{p}$ \\
\hline Age (year) ${ }^{\beta}$ & $28.0[25.0-32.0]$ & $29.0[26.0-32.0]$ & 0.701 & $29.0[26.0-32.0]$ & $31.0[29.0-32.0]$ & 0.082 \\
\hline $\begin{array}{c}\text { Educational } \\
\text { status }{ }^{\ddagger}\end{array}$ & & & & & & \\
\hline Primary & $0(0.0)$ & $34(11.6)$ & 0.999 & $32(11.3)$ & $2(11.8)$ & 0.424 \\
\hline Secondary & $2(28.6)$ & $76(25.9)$ & & $76(26.9)$ & $2(11.8)$ & \\
\hline University & $5(71.4)$ & $172(58.7)$ & & $165(58.3)$ & $12(70.6)$ & \\
\hline Higher & $0(0.0)$ & $11(3.8)$ & & $10(3.5)$ & $1(5.9)$ & \\
\hline $\begin{array}{c}\text { Interview } \\
\text { time for } \\
\text { gestational } \\
\text { period }{ }^{\ddagger}\end{array}$ & & & & & & \\
\hline
\end{tabular}




\begin{tabular}{|c|c|c|c|c|c|c|}
\hline $\begin{array}{l}\text { During } 1 \mathrm{st} \\
\text { trimester }\end{array}$ & $1(14.3)$ & $39(13.3)$ & 0.999 & $40(14.1)$ & $0(0.0)$ & 0.201 \\
\hline $\begin{array}{l}\text { During 2nd } \\
\text { trimester }\end{array}$ & $1(14.3)$ & $71(24.2)$ & & $66(23.3)$ & $6(35.3)$ & \\
\hline $\begin{array}{l}\text { During 3rd } \\
\text { trimester }\end{array}$ & $5(71.4)$ & $183(62.5)$ & & $177(62.5)$ & $11(64.7)$ & \\
\hline Gravidity ${ }^{\beta}$ & $1.0[1.0-2.0]$ & $1.0[1.0-2.0]$ & 0.545 & $1.0[1.0-2.0]$ & $2.0[1.0-2.0]$ & 0.279 \\
\hline Parity ${ }^{\beta}$ & $0.0[0.0-1.0]$ & $0.0[0.0-1.0]$ & 0.864 & $0.0[0.0-1.0]$ & $1.0[0.0-1.0]$ & 0.088 \\
\hline \multirow[t]{3}{*}{ Abortion ${ }^{\beta}$} & $0.0[0.0-0.0]$ & $0.0[0.0-0.0]$ & 0.257 & $0.0[0.0-0.0]$ & $0.0[0.0-0.0]$ & 0.297 \\
\hline & \multicolumn{2}{|c|}{$\begin{array}{l}\text { Use of medication without knowing } \\
\text { being pregnant }\end{array}$} & & \multicolumn{2}{|c|}{ Prescription medication use } & \\
\hline & No $(n=139)$ & Yes $(n=161)$ & $\mathrm{p}$ & No $(n=15)$ & Yes $(n=285)$ & $\mathrm{p}$ \\
\hline Age $\left(\right.$ year) ${ }^{\beta}$ & $28.8 \pm 4.3$ & $29.5 \pm 4.4$ & 0.139 & $30.0[27.5-32.0]$ & $29.0[26.0-32.0]$ & 0.801 \\
\hline \multicolumn{7}{|l|}{$\begin{array}{l}\text { Educational } \\
\text { status }\end{array}$} \\
\hline Primary & $21(15.1)$ & $13(8.1)$ & 0.031 & $1(6.7)$ & $33(11.6)$ & 0.600 \\
\hline Secondary & $43(30.9)$ & $35(21.7)$ & & $5(33.3)$ & $73(25.6)$ & \\
\hline University & $71(51.1)$ & $106(65.8)$ & & $8(53.3)$ & $169(59.3)$ & \\
\hline Higher & $4(2.9)$ & $7(4.3)$ & & $1(6.7)$ & $10(3.5)$ & \\
\hline \multicolumn{7}{|l|}{$\begin{array}{l}\text { Interview } \\
\text { time for } \\
\text { gestational } \\
\text { period }{ }^{\ddagger}\end{array}$} \\
\hline $\begin{array}{l}\text { During 1st } \\
\text { trimester }\end{array}$ & $23(16.5)$ & $17(10.6)$ & 0.163 & $3(20.0)$ & $37(13.0)$ & 0.729 \\
\hline $\begin{array}{c}\text { During 2nd } \\
\text { trimester }\end{array}$ & $28(20.1)$ & $44(27.3)$ & & $3(20.0)$ & $69(24.2)$ & \\
\hline $\begin{array}{l}\text { During 3rd } \\
\text { trimester }\end{array}$ & $88(63.3)$ & $100(62.1)$ & & $9(60.0)$ & $179(62.8)$ & \\
\hline Gravidity ${ }^{\beta}$ & 2.0 [1.0-2.0] & $1.0[1.0-2.0]$ & 0.012 & $1.0[1.0-2.0]$ & $1.0[1.0-2.0]$ & 0.930 \\
\hline Parity $\beta$ & $1.0[0.0-1.0]$ & $0.0[0.0-1.0]$ & 0.001 & $0.0[0.0-1.0]$ & $0.0[0.0-1.0]$ & 0.961 \\
\hline \multirow[t]{3}{*}{ Abortion ${ }^{\beta}$} & $0.0[0.0-0.0]$ & $0.0[0.0-0.0]$ & 0.885 & $0.0[0.0-0.0]$ & $0.0[0.0-0.0]$ & 0.377 \\
\hline & \multicolumn{2}{|c|}{ Over-the-counter medication use } & & \multicolumn{2}{|c|}{ Herbal product use } & \\
\hline & No $(n=255)$ & Yes $(n=45)$ & $\mathrm{p}$ & No $(n=81)$ & Yes $(n=219)$ & $\mathrm{p}$ \\
\hline Age $\left(\right.$ year) ${ }^{\beta}$ & $29.1 \pm 4.4$ & $29.7 \pm 4.0$ & 0.407 & $28.5 \pm 4.3$ & $29.5 \pm 4.4$ & 0.086 \\
\hline \multicolumn{7}{|l|}{$\begin{array}{l}\text { Educational } \\
\text { status }{ }^{\ddagger}\end{array}$} \\
\hline Primary & $27(10.6)$ & $7(15.6)$ & 0.258 & $14(17.3)$ & $20(9.1)$ & 0.043 \\
\hline Secondary & $71(27.8)$ & $7(15.6)$ & & $20(24.7)$ & $58(26.5)$ & \\
\hline University & $147(57.6)$ & $30(66.7)$ & & $47(58.0)$ & $130(59.4)$ & \\
\hline Higher & $10(3.9)$ & $1(2.2)$ & & $0(0.0)$ & $11(5.0)$ & \\
\hline $\begin{array}{l}\text { Interview } \\
\text { time for } \\
\text { gestational } \\
\text { period } \neq 9\end{array}$ & & & & & & \\
\hline
\end{tabular}




\begin{tabular}{|c|c|c|c|c|c|c|}
\hline $\begin{array}{c}\text { During 1st } \\
\text { trimester }\end{array}$ & $37(14.5)$ & $3(6.7)$ & 0.134 & $12(14.8)$ & $28(12.8)$ & 0.899 \\
\hline $\begin{array}{c}\text { During 2nd } \\
\text { trimester }\end{array}$ & $64(25.1)$ & $8(17.8)$ & & $19(23.5)$ & $53(24.2)$ & \\
\hline $\begin{array}{c}\text { During 3rd } \\
\text { trimester }\end{array}$ & $154(60.4)$ & $34(75.6)$ & & $50(61.7)$ & $138(63.0)$ & \\
\hline Gravidity $\beta$ & $1.0[1.0-2.0]$ & $1.0[1.0-2.0]$ & 0.216 & $1.0[1.0-2.0]$ & $1.0[1.0-2.0]$ & 0.229 \\
\hline Parity $\beta$ & $0.0[0.0-1.0]$ & $0.0[0.0-1.0]$ & 0.396 & $0.0[0.0-1.0]$ & $0.0[0.0-1.0]$ & 0.475 \\
\hline Abortion $\beta$ & $0.0[0.0-0.0]$ & $0.0[0.0-0.0]$ & 0.418 & $0.0[0.0-0.0]$ & $0.0[0.0-0.0]$ & 0.363 \\
\hline
\end{tabular}

${ }^{+}:$Mean \pm standard deviation, ${ }^{*}: n(\%),{ }^{\beta}$ : median [range].

There was a significant difference between educational status and use of medication without knowing being pregnant $(\mathrm{p}=0.031)$. The median number of pregnancy and live births were significantly lower in women who use medications without knowing being pregnant $(\mathrm{p}=0.012$ and $\mathrm{p}=0.001)$.

There were significantly more women who do not use herbal medications with primary education compared with those with herbal product use $(\mathrm{p}=0.043)$.

In Table 4, correlation analysis between age and the counts of different medications is given. There was a significant positive correlation between age and herbal medication use $(\mathrm{r}=0.127, \mathrm{p}=0.028)$. Age was not correlated with other types of medications ( $\mathrm{p}>0.05$ for all).

Table 4. Correlation analysis of age and gestational week, and use of different types of medications.

\begin{tabular}{ccccc}
\hline & \multicolumn{2}{c}{ Age } & \multicolumn{2}{c}{ Gestational age (week) } \\
\hline & Spearman's rho & p-value & Spearman's rho & p-value \\
\hline Overall medications & 0.097 & 0.094 & 0.267 & $<0.001$ \\
\hline $\begin{array}{c}\text { Prescription } \\
\text { medications }\end{array}$ & 0.068 & 0.242 & 0.244 & $<0.001$ \\
\hline $\begin{array}{c}\text { Over-the-counter } \\
\text { medications }\end{array}$ & 0.062 & 0.286 & 0.089 & 0.124 \\
\hline $\begin{array}{c}\text { Herbal products } \\
\text { Medications in } \\
\text { Category A }\end{array}$ & 0.127 & 0.028 & -0.034 & 0.563 \\
\hline $\begin{array}{c}\text { Medications in } \\
\text { Category B }\end{array}$ & 0.069 & 0.230 & 0.250 & $<0.001$ \\
\hline $\begin{array}{c}\text { Medications in } \\
\text { Category C }\end{array}$ & 0.101 & 0.311 & -0.019 & 0.738 \\
\hline $\begin{array}{c}\text { Medications in } \\
\text { Category D }\end{array}$ & -0.014 & 0.082 & 0.121 & 0.035 \\
\hline
\end{tabular}

Correlation analysis revealed significant differences between gestational age and the counts of overall medications, prescription medications, medications in Category A and Category C. As the gestational age increased, the number of 
medications in these subgroups significantly increased ( $\mathrm{p}<0.05$ for all).

In Table 5, the medications' distribution in each the FDA pregnancy risk category on different uses of medications is given. Medications in Category A was the most common medication used in various uses. Compared with Category B, medications in Category $\mathrm{C}$ were more commonly used considering overall, prescription, over-the-counter uses, and cases without doctors' recommendations.

Table 5. Distribution of the FDA pregnancy risk categories based on different medication use.

\begin{tabular}{cccccc}
\hline & $\begin{array}{c}\text { Overall } \\
\text { medication } \\
\text { use }(\mathbf{n}=\mathbf{2 9 3})\end{array}$ & $\begin{array}{c}\text { Prescription } \\
\text { medication } \\
\text { use }(\mathbf{n = 2 8 5})\end{array}$ & $\begin{array}{c}\text { Over-the- } \\
\text { counter } \\
\text { medication } \\
\text { use }(\mathbf{n}=\mathbf{4 5})\end{array}$ & $\begin{array}{c}\text { Use of medication } \\
\text { without doctors' } \\
\text { recommendation } \\
\mathbf{( n = 1 7 )}\end{array}$ & $\begin{array}{c}\text { Use of } \\
\text { medication } \\
\text { without knowing } \\
\text { being pregnant } \\
\text { (n=43) }\end{array}$ \\
\hline $\begin{array}{c}\text { Medications in } \\
\text { Category A }\end{array}$ & $286(97.6)$ & $280(98.2)$ & $43(95.6)$ & $208(95)$ & $17(100)$ \\
\hline $\begin{array}{c}\text { Medications in } \\
\text { Category } B^{\ddagger}\end{array}$ & $53(18.1)$ & $52(18.2)$ & $8(17.8)$ & $39(17.8)$ & $4(23.5)$ \\
\hline $\begin{array}{c}\text { Medications in } \\
\text { Category } C^{\ddagger}\end{array}$ & $100(34.1)$ & $96(33.7)$ & $15(33.3)$ & $78(35.6)$ & $4(23.5)$ \\
\hline $\begin{array}{c}\text { Medications in } \\
\text { Category } D^{\ddagger}\end{array}$ & $7(2.4)$ & $7(2.5)$ & $1(2.2)$ & $5(2.3)$ & $0(0)$ \\
\hline
\end{tabular}

${ }^{*}: n(\%)$.

The use of medications in Category $\mathrm{C}$ was significantly higher in the third trimester than the first and second trimesters $(\mathrm{p}=0.002)$. Herbal medications did not show any significant change between the trimesters $(p=0.899)$, details are given Table 6.

Table 6. Distribution of the FDA pregnancy risk categories based on different gestational periods.

\begin{tabular}{ccccc}
\hline & $\begin{array}{c}\text { 1st trimester } \\
(\mathbf{n = 4 0 )}\end{array}$ & $\begin{array}{c}\text { 2nd trimester } \\
(\mathbf{n = 7 2 )}\end{array}$ & $\begin{array}{c}\text { 3rd trimester } \\
(\mathbf{n = 1 8 8})\end{array}$ & $\mathbf{p}$-value \\
\hline $\begin{array}{c}\text { Medications in } \\
\text { Category A }\end{array}$ & $38(95.0)$ & $69(95.8)$ & $179(95.2)$ & 0.999 \\
\hline $\begin{array}{c}\text { Medications in } \\
\text { Category B }\end{array}$ & $9(22.5)$ & $10(13.9)$ & $34(18.1)$ & 0.504 \\
\hline $\begin{array}{c}\text { Medications in } \\
\text { Category C }\end{array}$ & $5(12.5)$ & $20(27.8)$ & $75(39.9)$ & 0.002 \\
\hline $\begin{array}{c}\text { Medications in } \\
\text { Category } D^{\ddagger}\end{array}$ & $0(0.0)$ & $0(0.0)$ & $7(3.7)$ & 0.204 \\
\hline Herbal products & $28(70.0)$ & $53(73.6)$ & $138(73.4)$ & 0.899 \\
\hline
\end{tabular}

${ }^{*}: n(\%)$.

Medication use during pregnancy depends on highly on the risk-benefit ration. The possible harmful effects of medications on fetus has been a matter of con- 
cern for many decades. In some occasions medication use is inevitable especially in patients with chronic diseases or those who develop serious acute diseases that require immediate treatment. In these cases, the choice of the most appropriate medication becomes significant. This study is among a few carried out in Turkey to analyze the use of medications during pregnancy. The results reflect common use of medications among females before and during pregnancy. Although most medications were routinely used during pregnancy, the presence of chronic and the presentation of some health conditions that needed treatment in some patients may have contributed to the high rate of medication use in the study population. Folic acid is recommended to prevent neural tube defects in neonates and iron replacement is also recommended to prevent pregnancy-related anemia ${ }^{18-20}$. There were fewer patients using folic acid as most of the study population were in their and and 3rd trimesters. The need for folic acid, on the other hand, increases prenatally through the 1 st trimester $^{20}$. Although the use of vitamin complexes is recommended in patients with obvious need for replacement, their use was common among the study population.

The FDA pregnancy risk category of $33,3 \%$ and $17,7 \%$ of the prescribed medications recorded in this study were $\mathrm{C}$ and $\mathrm{B}$ respectively, while the category of $95,3 \%$ of these medications was A. Similarly, most medications taken without doctor's advice nor prescription were in the $\mathrm{C}$ category. In a study involving a large patient population in the United States, it was reported that $50 \%$ of the medications used in pregnancy were in category B and $37 \%$ were in category $\mathrm{C}^{21}$. This is similar to our results, but there were fewer medications in the $\mathrm{B}$ category as we recorded more medications in category C. In a previous study, $6,3 \%$ and $3,3 \%$ of prescribed medications were reported to be in the $\mathrm{D}$ and $\mathrm{X}$ categories respectively ${ }^{22}$. In this study, only one patient was prescribed acetylsalicylic acid in her 3 rd trimester. Acetylsalicylic acid has been associated with central nervous system, circulatory and skeletal anomalies when used in early pregnancy and prolongation of birth when used at high doses in the end stage of pregnancy ${ }^{14}$. So, it may be used to delay birth in patients with this indication and it was used for this indication in two patients with premature birth risk. There was only one category $\mathrm{X}$ herbal supplement that the patient used without her doctor's consent and it contains Panax ginseng.

The most commonly used medication without doctor's consent was acetaminophen. Although its use at the late stages of pregnancy was associated with breathing difficulties in infants, its FDA pregnancy category is B and it is the safest analgesic during pregnancy ${ }^{14}$. The use of omega 3 during pregnancy is on the rise as seen in the results. A study revealed that omega 3 reduced the risk 
of teratogenesis in pregnant women with depression ${ }^{23}$. Although many positive effects are linked to omega 3 , there is still need for precise data to certify its use during pregnancy.

About 52,6\% of patients explained using some medications and supplements before they were confirmed pregnant. The most commonly used medication was folic acid. The use of folic acid prenatally was shown to effectively prevent neural tube defect risk ${ }^{24}$. This shows that most pregnancies were planned, and most women were aware of the positive effects of folic acid. Two patients who had failed contraception reported using norethisterone which is in the X category. The use of oral contraceptives in the 1st trimester was shown to have limited teratogenic effect on the embryo ${ }^{25}$.

The FDA later decided that the categorical system was not sufficient to characterize and communicate risks to drug use in pregnancy, and that a 'narrated' narrative based on available animal and human data is more appropriate for such a purpose. Despite the changes, the old classification system is still used in various sources.

Herbal use was common in the study population. Most women use these products for no special reason. Some used some tea infusion as alternatives to medications to prevent nausea etc. Studies have shown that herbal products are often used to treat nausea, vomiting, anxiety, stress, cough, common cold, indigestion and constipation ${ }^{26-28}$. The caffeine limit was exceeded by ten patients. There are controversies on the limit of daily caffeine intake during pregnancy, while the WHO suggests 300 mg to be the maximum ${ }^{16}$, the American College of Obstetricians and Gynecology suggests the consumption of less than $200 \mathrm{mg} /$ day $^{29}$. A meta-analysis study revealed a significant reduction in birth weight and placental weight in babies born to pregnant women who received high doses of caffeine during pregnancy. Therefore, it is recommended to limit the intake of caffeine during pregnancy ${ }^{30}$. Also the risk of low birth weight was reported to increases as caffeine intake increases ${ }^{31}$. Considering the consumption of black tea and coffee in Turkey, the presence of only a few women exceeding the caffeine limit suggest that pregnant women are conscious of the possible negative effects of caffeine on their baby.

Since the doses and time of herbal products used in the study are not included, larger-scale studies are required.

There are a few limitations of our study. Since the sample size is small, larger studies are needed. Limited data have been collected, especially on herbal products.

The new classification determined by the FDA should be used in future research. 


\section{ETHICAL COMMITTEE APPROVAL}

Approval from Istanbul Medipol University Non-Interventional Clinical Research Ethics Committee (approval date: 16.11.2016 / approval no: 517).

\section{CONFLICT OF INTEREST}

The authors declare that there is no conflict of interest.

\section{AUTHOR CONTRIBUTIONS}

Concept - R.M.U., R.B., A.K.Ş., E.K.K. C.C.; Design - R.M.U., E.K.K.; Supervision - R.M.U., E.K.K.; Resources - R.M.U., R.B., A.K.Ş.; Materials - R.M.U., E.K.K.; Data Collection and/or Processing -R.B., A.K.Ş.; Analysis and/or Interpretation - R.M.U., E.K.K., C.C.; Literature Search - R.M.U., E.K.K., R.B., A.K.Ş., C.C.; Writing - R.M.U., E.K.K., C.C., Critical Reviews - R.M.U., E.K.K., C.C., R.B., A.K.Ş.

\section{ACKNOWLEDGEMENT}

The authors thankful to Bağcilar Medipol Mega University Hospital for providing the opportunity to do this research.

\section{DISCLAIMER}

The authors alone are responsible for the content and writing of the paper. 


\section{REFERENCES}

1. Thomas SH, Yates LM. Prescribing without evidence - pregnancy. Br J Clin Pharmacol, 2012; 74(4): 691-697. https://doi.org/10.1111/j.1365-2125.2012.04332.x

2. Pariente G, Leibson T, Carls A, Adams-Webber T, Ito S, Koren G. Pregnancy-Associated Changes in Pharmacokinetics: A Systematic Review. PLoS Med, 2016; 13(11): e100216o. https://doi.org/10.1371/journal.pmed.1002160

3. Kfuri TA, Morlock L, Hicks RW, Shore AD. Medication errors in obstetrics. Clin Perinatol, 2008; 35(1): 101-ix. https://doi.org/10.1016/j.clp.2007.11.015

4. Mburu G, Ayon S, Mahinda S, Kaveh K. Determinants of Women's Drug Use During Pregnancy: Perspectives from a Qualitative Study. Matern Child Health J, 2o20; 24(9): 1170-1178. https://doi.org/10.1007/s10995-020-02910-w

5. Al Essa M, Alissa A, Alanizi A, Bustami R, Almogbel F, Alzuwayed O, et al. Pregnant women's use and attitude toward herbal, vitamin, and mineral supplements in an academic tertiary care center, Riyadh, Saudi Arabia. Saudi Pharm J, 2019; 27(1): 138-144. https://doi.org/10.1016/j. jsps.2018.09.007.

6. Schaefer C. Medications during pregnancy and lactation, treatment options and risk assessment. $3^{\text {th }}$ edition. USA: Elsevier; 2015. pp. 2-24.

7. Sachdeva P, Patel BG, Patel BK. Drug use in pregnancy; a point to ponder!. Indian J Pharm Sci, 2009; 71(1): 1-7. https://doi.org/10.4103/0250-474X.51941.

8. Radziejewska A, Chmurzynska A. Folate and choline absorption and uptake: Their role in fetal development. Biochimie, 2019; 158: 10-19. https://doi.org/10.1016/j.biochi.2018.12.002.

9. Anderson GD. Pregnancy-induced changes in pharmacokinetics: a mechanistic-based approach. Clin Pharmacokinet, 2005; 44(10): 989-1008. https://doi.org/10.2165/oooo3088$200544100-00001$.

10. Koren G, Pariente G. Pregnancy- Associated Changes in Pharmacokinetics and their Clinical Implications. Pharm Res, 2018; 35(3): 61. https://doi.org/10.1007/s11095-018-2352-2.

11. Feghali M, Venkataramanan R, Caritis S. Pharmacokinetics of drugs in pregnancy. Semin Perinatol, 2015; 39(7): 512-519. https://doi.org/10.1053/j.semperi.2015.08.003.

12. John LJ, Shantakumari N. Herbal Medicines Use During Pregnancy: A Review from the Middle East. Oman Med J, 2015; 30(4): 229-236. https://doi.org/10.5001/omj.2015.48.

13. Olukman M, Parlar A, Orhan CE, Orhan AE. Gebelerde İlaç Kullanimi: Son Bir Yillik Deneyim. J Turk Soc Obs Gynecol, 2006; 3(4): 255-261.

14. Ayele Y, Mekuria AN, Tola A, Mishore KM, Geleto FB. Prescription drugs use during pregnancy in Ethiopia: A systematic review and meta-analysis. SAGE Open Med, 2o2o; 8: 2050312120935471. https://doi.org/10.1177/2050312120935471.

15. WHO Recommendations. 2016. Retrieved from https://www.who.int/elena/titles/caffeinepregnancy/en/ (accessed on November 1, 2016).

16. Naser LR, Sameh A, Muzaffar I, Omar AR, Ahmed MA. Comparative evaluation of caffeine content in Arabian coffee with other caffeine beverages. African J Pharm Pharmacol, 2018; 12(2): 19-26. https://doi.org/10.5897/AJPP2017.4880.

17. Karabulut A, Sevket O, Acun A. Iron, folate and vitamin B12 levels in first trimester pregnancies in the Southwest region of Turkey. J Turk Ger Gynecol Assoc, 2011; 12(3): 153-156. https:// 
doi.org/10.5152/jtgga.2011.36

18. Açkurt F, Wetherilt H, Löker M, Hacibekiroğlu M. Biochemical assessment of nutritional status in pre- and post-natal Turkish women and outcome of pregnancy. Eur J Clin Nutr, 1995; 49(8): 613-622.

19. Lumley J, Watson L, Watson M, Bower C. Periconceptional supplementation with folate and/or multivitamins for preventing neural tube defects. Cochrane Database Syst Rev, 2oo1; (3): CDo01056. https://doi.org/10.1002/14651858.cdoo1056.

20. Andrade SE, Gurwitz JH, Davis RL, Chan KA, Finkelstein JA, Fortman K, et al. Prescription drug use in pregnancy. Am J Obstet Gynecol, 2oo4; 191(2): 398-407. https://doi. org/10.1016/j.ajog.2004.04.025.

21. Özbudak H, Ünal AZ, Sabuncuoğlu S. Gebelikte non-steroidal antiinflamatuvar ilaçların kullanımının değerlendirilmesi. Marmara Pharm J, 2016; 20(2): 64-71. doi:10.12991/ mpj.20162059818.

22. Su KP, Huang SY, Chiu TH, Huang KC, Huang CL, Chang HC, et al. Omega-3 fatty acids for major depressive disorder during pregnancy: results from a randomized, double-blind, placebo-controlled trial. J Clin Psychiatry, 2oo8; 69(4): 644-651. https://doi.org/10.4088/jcp. v69no418.

23. Greenberg JA, Bell SJ, Guan Y, Yu YH. Folic Acid supplementation and pregnancy: more than just neural tube defect prevention. Rev Obstet Gynecol, 2011; 4(2): 52-59.

24. Savolainen E, Saksela E, Saxén L. Teratogenic hazards of oral contraceptives analyzed in a national malformation register. Am J Obstet Gynecol, 1981; 140(5): 521-524. https://doi. org/10.1016/0002-9378(81)90227-1.

25. Kıssal A, Çevik Güner Ü, Batkın Ertürk D. Use of herbal product among pregnant women in Turkey. Complement Ther Med, 2017; 30: 54-6o. https://doi.org/10.1016/j.ctim.2016.11.001.

26. Muñoz Balbontín Y, Stewart D, Shetty A, Fitton CA, McLay JS. Herbal Medicinal Product Use During Pregnancy and the Postnatal Period: A Systematic Review. Obstet Gynecol, 2o19; 133(5): 920-932. https://doi.org/10.1097/aog.oooooooooooo3217.

27. Costantine MM. Physiologic and pharmacokinetic changes in pregnancy. Front Pharmacol, 2014; 5: 65. https://doi.org/10.3389/fphar.2014.00065.

28. American College of Obstetricians and Gynecologists Clinical Guidance Committee Opinion, 2016. Retrived from. https://www.acog.org/clinical/clinical-guidance/committee-opinion/articles/2010/o8/moderate-caffeine-consumption-during-pregnancy (accessed on November 1, 2016).

29. Chen LW, Wu Y, Neelakantan N, Chong MF, Pan A, van Dam RM. Maternal caffeine intake during pregnancy is associated with risk of low birth weight: a systematic review and dose-response meta-analysis. BMC Med, 2014; 12: 174. https://doi.org/10.1186/s12916-014-0174-6.

30. Rhee J, Kim R, Kim Y, Tam M, Lai Y, Keum N, et al. Maternal Caffeine Consumption during Pregnancy and Risk of Low Birth Weight: A Dose-Response Meta-Analysis of Observational Studies. PLoS One, 2015; 10(7): eo132334. https://doi.org/10.1371/journal.pone.0132334. 